\title{
Analyzing the Use of ICT for Professional Development among Secondary School Teachers in Tanzania
}

\author{
Rukia Mwifunyi \\ The University of Dodoma \\ P.O Box 490, Dodoma
}

\author{
Nyaura Kibinda \\ The University Dodoma \\ P.O Box 490, Dodoma
}

\begin{abstract}
Teachers' Professional Development refers to a variety of activities both formal and informal, which is designed for a personal and professional growth for teachers. The advancement of technology has been recognized to play a valuable role in developing and improving the teaching and learning situations. This study, aims at analyzing the use of ICT in Teachers' professional among the Tanzanian Secondary School teachers. Data used in this study, were collected through a field data collection. A total of 139 questionnaires were filled and analyzed by using SPSS package. Multiple regression models were used for analysis. Factors which were included in the model explain the variability in teaching professional development by $43.30 \%$ as $R$ square $=0.433$. F value was equal to 3.381 and $\mathrm{p}$-value $=0.008$ implies that the overall model is reasonable at $5 \%$ level of significance. This model is statistically fit to check the use of ICT in teaching professional development.
\end{abstract}

\section{Keywords}

Professional Development, Information and Communication Technology, ICT, Teacher Professional Development

\section{INTRODUCTION}

The term 'Information and Communication Technology' (ICT) first, appeared in the mid-1980s and was defined as "All kinds of electronic systems used for broadcasting telecommunications and mediated communications", with examples including personal computers, Televisions, cell phones, internet and electronic payment systems and computers [1]. ICT plays a great role in shifting the society from the information to the knowledge community.

ICT is a powerful enabler of development which is used to encompass technological innovation and convergence in information and communication, leading to changes in the social interaction, economic and business practices, enhancement of networking, education, health, leisure and entertainment. ICT also, have the potential to improve interaction between Governments and citizens, fostering transparency and accountability in governance [2].

Education is not only limited to teaching students according to the prescribed syllabus at a specific school level. It has much broader objectives, goals and other concepts. Education changes in particular those changes associated with the rhetoric of the global information society, requires staff development activities. In order for changes to be affected in the classroom, additional technical and pedagogical support is necessary[3], [4].

It is important for teachers to have ongoing and regular opportunities to learn from each other which is known as professional development. An ongoing professional development keeps teachers up-to-date on a new research on how children learn, emerging technology tools for the classroom, new curriculum resources, and others. The best professional development is an ongoing, experiential, collaborative, and connected to and derived from working with students and understanding their culture [5].

Professional developments could be either formal experiences (as attending workshops or professional meetings, mentoring, etc.) or informal experiences; such as reading professional publications, watching television documentaries related to any academic disciplines[6], [7]. In literature, it has been observed that a professional development through trainings and workshops is very expensive due the huge number of teachers[6].

An ongoing learning, can easily be achieved through an effectively usage of the technological advancement. In general, the new technologies have been recognized to play a valuable role in developing and improving the teaching and learning situations. The usage of technology in education and other fields remains an emerging field of study, in which users must be sensitized on using internet for professional development, largely because technological advances introduce new instructional possibilities [8], [9].

ICT in teachers' professionalism have the following roles: To improve the knowledge of the content in different subject matters and knowledge for the new concepts, addresses the identified gaps in students' achievements, improve problem solving skills, innovation and creativity and used as a tool for organization and management in schools. Moreover, it can be used as means of collaboration with teachers from different areas with different experiences in teaching, for knowledge sharing. Therefore, ICT is a very useful tool for informal and a continuous lifelong learning[10].

The advancement of technology in Africa with internet penetration is increasing dramatically from year to year. According to ITU 2015, the internet penetration has increased to $27.8 \%$. In Tanzania, the internet penetration have increased from $1.3 \%$ in 2009 to $14.9 \%$ in 2015 . On other hand the mobile penetration have reached to $70 \%$ in 2015 [11]. Out of $14.9 \%$ of the internet users, $5.3 \%$ are using for social networking [12]. Despite the expansion of the Internet penetration in Tanzania, the body of an empirical research investigating the level of ICT usage for the professional development is still relatively small.

This study, aims at analyzing the use of ICT in Teachers' Professional Development (TPD) in Tanzania Secondary School Teachers. The following research questions were answered: What is the level of importance of ICT in the professional development?, Is there a significant relationship between professional development and teachers' level of ICT 
usage? And Which factors hinder the use of ICT in professional development?

\section{RELATED WORKS}

Many researches, have been reporting the use of ICT in Teachers' Professional Development in different countries as follows.

According to [6], it was discussed that, the $21^{\text {st }}$ century has brought a greater demand for the Malaysians to produce quality teachers; the road ahead is not going to be easy in producing the next generation of them. The government has taken great measures in achieving its graduate target in primary and secondary education, narrowing the digital divide and integrating ICT in the teaching and learning process.

According to [13], the efforts for Namibia for the use of ICT for TPD have been examined, and has revealed that, Namibia is ahead of its African counterparts in terms of the usage of ICT in instructions and teachers' education, its level of infrastructure and its commitment in ICT for teacher and student learning. However, it has been observed that, Namibia faces some challenges like, technical support, focusing on ICT skills training at the expense of integration and sustainability of projects, in the usage of ICT for TPD is questionable.

According to [7], teachers' and the usage of ICT for professional development in Botswana have been investigated. It has been reported that, Botswana's ICT infrastructure in schools is very good but not fully utilized due to these challenges: lack of electricity in many rural areas and a high charges for the internet usage. In [14] it was reported that, the global investment in ICT to improve teaching and learning in schools has been initiated by many governments but the ICT adoption in the education sector lacked behind the business sector.

In Tanzania, the initiatives of equiping schools with ICT infrastructures began in 2010 in which almost 200 schools have been provided with computers, projectors and others equipments, which helps teachers in Teaching and Learning. The Internet infrastracture installation in those schools have started. Trainings to teachers, on how to use ICT equipment started since 2014. However, it is not possible to train all teachers. All these initiatives would be successful if and only if, teachers will be self motivated to use ICT in their teaching professional.

\section{METHODS}

Data used in this study were collected through field data collection. A total of 150 questionnaires were administered and only 139 were returned/responded to. This gave the respondents a rate of $93.3 \%$ of all administered questionnaires. Data collected were analyzed by using the SPSS data analysis tool. Learning new concepts in the subject matter, addressing identified students' performance gaps, improving problem solving skills and creativity as well innovation, were used as the indicators of Teachers' Professional Development. Multiple regression models were used for analysis.

\section{RESULTS AND DISCUSSION 4.1.Data Description}

All respondents were found to have ICT devices; $20.5 \%$ computers (laptop and desktop) 59\% mobile phones and 20.5\% TV/radio. Furthermore $12.8 \%$ of the respondents indicated ICT devices were not important in teaching professional development, while $10.3 \%$ were neutral, $23.1 \%$ said that were important and $53.8 \%$ said that were very important.

Table 1 displays a descriptive statistics for the entire sample. Methods of acquiring teaching professional development were grouped into two groups ICT enabled and non ICT enabled methods. Training, seminars, workshops, and reading books (hard copy) were used as proxy, for non ICT enabled methods for achieving teaching professional development while reading e-books, reading professional publications, searching materials from internet, and watching documentaries related to academic discipline were used as a proxy for the use of ICT enabled method for achieving teaching professional development.

From the data description it was observed that teaching professional development occurs almost every time through reading hard copy books as depicted in Table 1 and Figure 1. This can be observed through the mean of professional development and reading hard copy books, which was 3.9615 equivalents to $79.23 \%$ and 3.8462 equivalents to $76.92 \%$ respectively. The mean of the level of importance of ICT devices in teaching professional development was 4.1795 equivalents to $83.59 \%$. This implies that, most respondents agreed that ICT devices were important in teaching professional development.

\subsection{Regression Results}

The model tested the relationship between teaching professional development and seven explanatory variables. Explanatory variables were analyzed in two levels; the first analysis was on ICT based and non ICT based methods, in order to find out the effect of ICT-based and non-ICT based methods for teaching professional development then, each variable was analyzed individually in order to find out the individual contribution of each variable in the TPD.

Factors which were included in the model explain the variability by $43.30 \%$ as $R$ square $=0.433$. $F$ value was equal to 3.381 and p-value $=0.008$ implies that, the overall model was reasonable at $5 \%$ level of significance. This model statistically is fit to check the use of ICT in Teaching Professional Development.

Table 1: Descriptive statistics

\begin{tabular}{|l|r|r|r|r|r|r|r|}
\hline & $\mathrm{N}$ & \multicolumn{1}{|c|}{ Range } & \multicolumn{1}{c}{$\begin{array}{c}\text { Minimu } \\
\mathrm{m}\end{array}$} & \multicolumn{1}{c|}{$\begin{array}{c}\text { Maxim } \\
\text { um }\end{array}$} & \multicolumn{1}{c|}{ Mean } & $\begin{array}{c}\text { Std. } \\
\text { Deviation }\end{array}$ & $\begin{array}{l}\text { Varianc } \\
\mathrm{e}\end{array}$ \\
\hline Age of respondents & 139 & 25.00 & 24.00 & 49.00 & 32.1316 & 6.49395 & 42.171 \\
\hline Teaching Professional development & 139 & 2.50 & 2.50 & 5.00 & 3.9615 & .55766 & .311 \\
\hline Training & 139 & 2.00 & 1.00 & 3.00 & 2.1282 & .73196 & .536 \\
\hline Seminar and workshops & 139 & 2.00 & 1.00 & 3.00 & 2.2051 & .76707 & .588 \\
\hline
\end{tabular}




\begin{tabular}{|l|r|r|r|r|r|r|r|}
\hline Reading books hard copy & 139 & 4.00 & 1.00 & 5.00 & 3.8462 & .74475 & .555 \\
\hline Reading books electronic copy & 139 & 3.00 & 1.00 & 4.00 & 2.1026 & .99459 & .989 \\
\hline Reading professional publications & 139 & 2.00 & 1.00 & 3.00 & 2.4103 & .71517 & .511 \\
\hline Searching materials from internet & 139 & 3.00 & 2.00 & 5.00 & 3.1538 & .81235 & .660 \\
\hline $\begin{array}{l}\text { Watching documentaries related to } \\
\text { academic discipline }\end{array}$ & 139 & 3.00 & 1.00 & 4.00 & 2.9487 & .39395 & .155 \\
\hline $\begin{array}{l}\text { Level of importance of ICT devices } \\
\text { in teaching professional }\end{array}$ & 139 & 3.00 & 2.00 & 5.00 & 4.1795 & 1.07292 & 1.151 \\
\hline
\end{tabular}

Table 2 : Coefficients of IT and non-IT enabled methods of acquiring teaching professional development

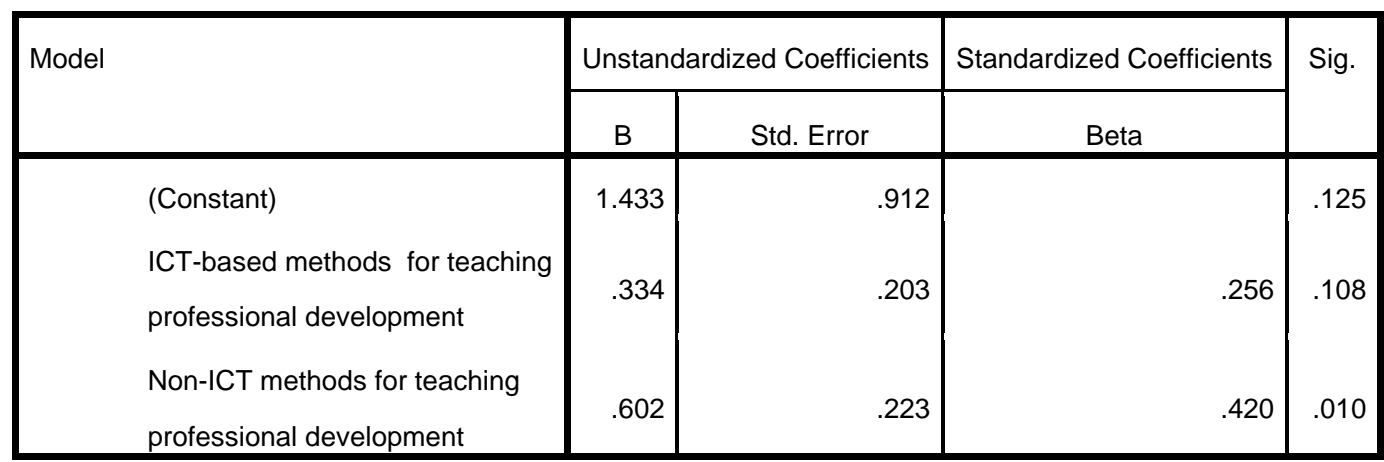

Table 3: Coefficients of variables for methods for acquiring teaching professional development

\begin{tabular}{|c|c|c|c|c|c|}
\hline \multirow[t]{2}{*}{ Mode } & & \multicolumn{2}{|c|}{$\begin{array}{c}\text { Unstandardized } \\
\text { Coefficients } \\
\end{array}$} & \multirow{2}{*}{$\begin{array}{c}\begin{array}{c}\text { Standardized } \\
\text { Coefficients }\end{array} \\
\text { Beta }\end{array}$} & \multirow[t]{2}{*}{ Sig. } \\
\hline & & B & $\begin{array}{l}\text { Std. } \\
\text { Error }\end{array}$ & & \\
\hline \multirow{8}{*}{1} & (Constant) & 2.384 & .993 & & .022 \\
\hline & Training & .344 & .136 & .451 & .017 \\
\hline & Seminars and workshops & .117 & .132 & .161 & .381 \\
\hline & Reading books hard copy & .231 & .118 & .308 & .060 \\
\hline & Reading books electronic copy & .193 & .097 & .344 & .055 \\
\hline & Reading professional publications & .137 & .151 & .176 & .370 \\
\hline & Searching materials from internet & -.183 & .139 & -.266 & .198 \\
\hline & $\begin{array}{l}\text { Watching documentaries related to academic } \\
\text { discipline }\end{array}$ & -.155 & .230 & -.110 & .503 \\
\hline
\end{tabular}




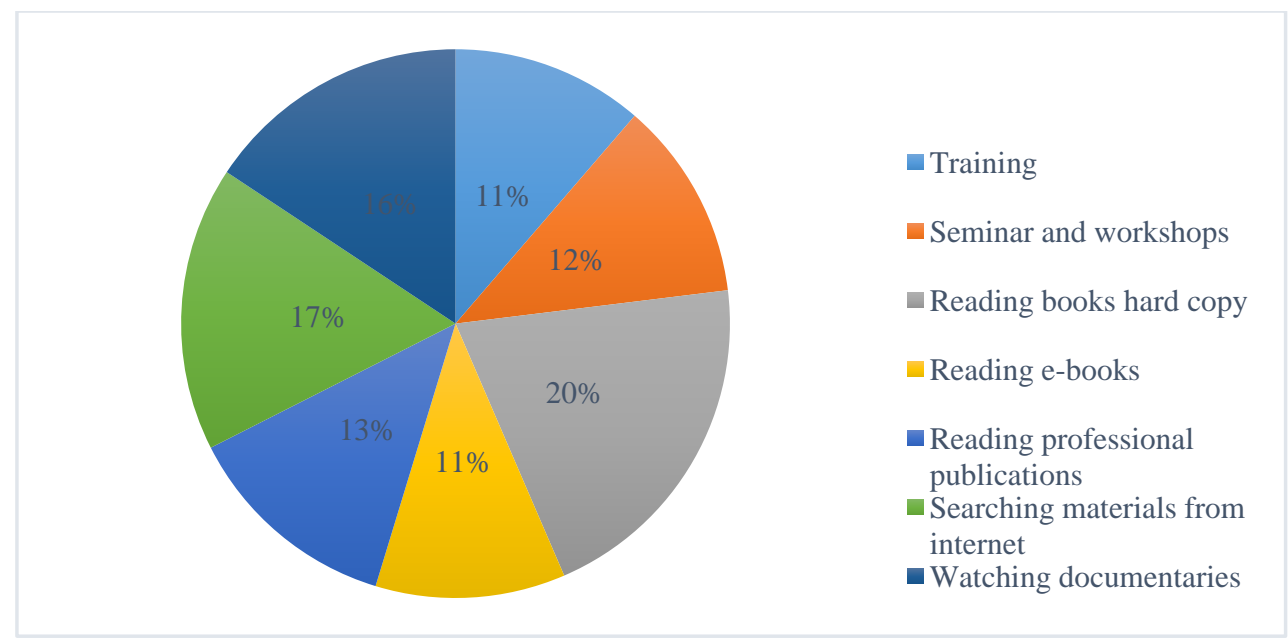

Figure 1: Methods for Acquiring Professional Development:

\subsection{Discussion of the Results}

The empirical evidence obtained suggest that there was a positive relationship between teaching professional development with both ICT-based, and non ICT based methods of acquiring TPD. The coefficient of non-ICT based methods of acquiring teaching professional development generally was significant at 5\% level of significance while the coefficient of ICT-base methods of acquiring teaching professional development, were not significant at $5 \%$ and $10 \%$ level of significance. Results are summarized in table 2 .

It was discovered that, teaching professional development had a positive association with training, seminars and workshops, reading hard copy books, reading e-books, and reading professional publications. The relationship for searching materials from the internet and watching documentaries related to academic discipline was negative. This negative relationship was not expected but might have occurred due to the possible limitations on the usage of ICT devices, in teaching professional development. Further details are shown in table 3.

The empirical evidence obtained from table 3 suggests that, the coefficient of training was significant at $5 \%$ level of significance while the coefficients of reading hard copy books and e-books were significant at $10 \%$ level of significance. Out of three non-ICT based explanatory variables, two were significant while out of four ICT based explanatory variables only one was significant. Hence, this congruence the argument that non-ICT based methods of teaching professional development were significant as compare to ICT based methods which were not significant.

Factors which hindered effectiveness utilization of ICT devices in teaching professional development were explored as depicted in figure 2. It was discovered that there was a high negative correlation between network unavailability, electricity problems, high internet costs, low knowledge on the usage of ICT devices, and lack of relevant electronic contents for the subject matter with the level of utilization of ICT devices, in teaching professional development. Evidence shown that, this relationship was significant

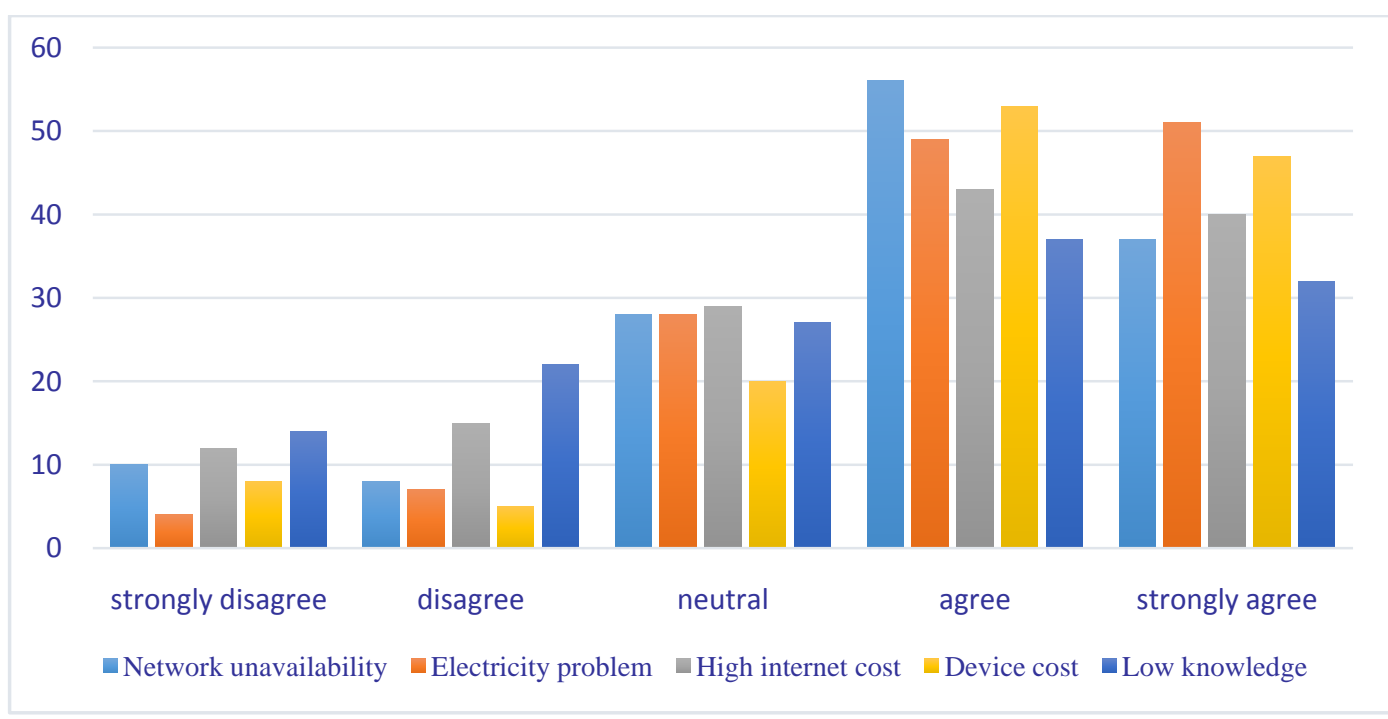

Figure 2: Factors affecting the use of ICT in Professional Development 


\section{CONCLUSION}

The effective TPD, addresses the core areas of teaching content, curriculum, assessment and instruction. Moreover, it should address teacher and student needs via approaches that were appropriate for conditions in schools, Be ongoing, sequenced, and cumulative, providing teachers opportunities to gain new knowledge and skills, reflect on changes in their teaching practice, and increase their abilities over time, Focus on students' learning outcomes in ways that enable teachers' to use their new knowledge and skills and model learnercentered instruction so that teachers experience and reflect on the learning activities, that they would lead. Once the ICT used effectively, all these could be attained. Furthermore, social media groups could serve as a professional development learning community for teachers.

Though it was discovered that, ICT devices were not significant in teaching professional development, their nonsignificance might have happened due to factors which hindered the effective utilization of ICT devices in teaching professional development. It is the role of government and other stakeholders to ensure that, these limitations are eliminated or reduced through the establishment of effective policies in the TPD and ensuring that relevant e-content are available.

Further research, might be done on a similar or different area by using a different approach in order to compliment the results or to find new trends on the contribution of ICT in the Teaching Professional Development.

\section{ACKNOWLEDGMENTS}

Our thanks to the stakeholders who have provided valuable contribution for the publication of this paper.

\section{REFERENCES}

[1] E. O. Ruth, R. Effurun, D. State, O. E. Paul, R. Effurun, D. State, A. K. Ejiro, R. Effurun, and D. State, "Information communication technology: a catalyst for enhancing the role of libraries in the creation of an information society," vol. 3, no. 2, pp. 39-47, 2015.

[2] E. Sandys, "Gender equality and empowerment of women through ICT Gender equality and empowerment," Women2000 and Beyond, 2005.
[3] M. Hooker, "Models and Best Practices in Teacher Professional Development," 2008.

[4] S. Quattlebaum, "Why Professional Development for Teachers is Critical," Evolllution. 2012.

[5] Edutopia, "Bookmark Why Is Teacher Development Important?: Because Students Deserve the Best," 2008. [Online]. Available:http://www.edutopia.org/teacherdevelopment-introduction. [Accessed: 17-Jan-2016].

[6] H. Jamil, N. A. Razak, R. Raju, and A. R. Mohamed, "Teacher Professional Development in Malaysia: Issues and Challenges," 2011.

[7] E. Ifeoma and E. Olusola.adu, "The Teacher and the Use of ICT for Professional Development," in International conference on ICT for Africa, 2013, 2013.

[8] C. of P. E. CEP, "Effective Professional Development in an Era of High Stakes Accountability," 2013.

[9] N. J. Al-zaidiyeen and L. L. Mei, "Teachers 'Attitudes and Levels of Technology Use in Classrooms: The Case of Jordan Schools," vol. 3, no. 2, pp. 211-218, 2010.

[10] H. H. Sandra, "Teacher Professional Development : It 's Not an Event, It 's a Process," CORD, 2003.

[11] BuddleComm, "Tanzania - Telecoms, Mobile and Broadband - Statistics and Analyses," 2015. [Online] Available: http://www.budde.com.au/Research/TanzaniaTelecoms-Mobile-and-Broadband-Statistics-andAnalyses.html?r=51. [Accessed: 24-Jan-2016]

[12] ITU, "Internet World Statics: Usage and Population Statistics," Internet Coaching Library, 2015. [Online]. Available: http://www.internetworldstats.com/africa.htm. [Accessed: 24-Jan-2016].

[13] M. Burns, "Using ICT for Teacher Professional Development in Namibia," infodev, no. 1, pp. 1-18, 2006.

[14] C. Buageng-andoh, "Factors influencing teachers ' adoption and integration of information and communication technology into teaching: A review of the literature," vol. 8, no. 1, pp. 136-155, 2012. 